\title{
Measurement of Sigma Level from Consumer Sound Side in Fried Oil Product
}

\author{
Julianus Hutabarat, Riwayati Triswanti, and Renny Septiari \\ Department of Industrial Engineering, Institut Teknologi Nasional Malang, Malang \\ e-mail: julianus1961@lecturer.itn.ac.id
}

\begin{abstract}
The industry of goods and services is inseparable and is highly related to customers, so customer satisfaction is always the main goal. A company will be able to continue to survive in the market as long as it can maintain good quality in order to satisfy customers. To find out which cooking oil products on the market are in accordance with the wishes of the customer or the voice of customer, a customer satisfaction survey or questionnaire was conducted which was distributed to mothers in Griya Asri housing complex, Purwosari - Pasuruan, by comparing 3 brands of cooking oil which were all made from oil palm, namely: brands A, B and C. From the questionnaire will be known what is needed or desired by the customer so the company can determine CTQ (critical to quality) based on the voice of customer. The questionnaire that has been distributed is then calculated sigma level and also made a comparison between the level of importance with the level of customer satisfaction. The results show that the lowest level of sigma for brand A cooking oil in CTQ is not turbid fast and cheap price is 1.86, with the position in quadrant $A$ (Attention) while for $B$ brand low level sigma cooking oil is in CTQ for low price, namely 1.83 with a position in quadrant $A$ (Attention) and finally the lowest level of sigma for $\mathrm{C}$ brand cooking oil is in CTQ Not quickly cloudy, that is 1.97 with a position in quadrant A (Attention). So it can be concluded that the CTQ that needs to be improved and considered both from the sigma level and the quadrant position for the three types of cooking oil products is not turbid fast and cheap prices.
\end{abstract}

Keywords - Voice of customer, CTQ, Cooking Oil.

\section{I.INTRODUCTION}

$\mathrm{T}$ HE QUALITY of a product is generally associated and measured from the degree of customer satisfaction with the product. This means that the higher level of customer satisfaction with a product, the customer will call it a quality product. So that every company will always try to create a product that can meet customer desires.

Companies that have a focus on customer satisfaction and assume that customers are company assets will be able to get customers who are loyal to a product that will automatically be a benefit for a company. Conversely, if a company cannot meet the wants or needs of customers, it is very likely that customers will switch to other products and result in decreased sales of a product.

For this reason, it is necessary to measure the level of customer satisfaction, one of which is through customer satisfaction surveys by distributing questionnaires. This questionnaire was distributed to find out the level of customer satisfaction in 3 cooking oil products namely; A, B and C, the results of which can be used as input or advice to the company in determining Critical To Quality (CTQ) as expected by the customer, the intended cooking oil product as shown in Figure 1.
Figure 1, is 3 types of cooking oil which are all made from palm oil and the level of satisfaction will be measured compared to the level of importance that will be obtained from the results of the questionnaire distribution, where the questionnaire contains the CTQ desired by the customer. The questionnaire will also be measured regarding the sigma level of each CTQ so that it can be taken into consideration for companies to make improvements.

Research on determining CTQ has also been carried out by Dongwon Kim [1] with the title "CTQ For Service Quality Management Using Web-Based Voc: With Focus On Hotel Business" where this study concluded that the purpose of the study was to obtain CTQ for management strategies the quality of web-based customer service (VOC) is changed to CTQ which is measured using sentiment analysis where the sentiment value obtained is used as quantitative data of CTQ. To get hotel service CTQ used 2 ways, first, the process of making CTQ data using the KJ method and second is to measure CTQ results. So sentiment analysis can be done on key words related to CTQ to turn CTQ into quantitative and measurable characteristics.

Roslina Mustapha and Nurul Fadly Habidin [2] also conducted a study entitled "Using DMAIC in Improvement of Customer Satisfaction and Facilities provided at Commuter Stations" with the conclusion that as an organization that monopolizes railroad services KTM should provide the best service for passenger satisfaction. For this reason a number of approaches have been taken to ensure KTM continues to improve productivity and profitability based on the voice of the customer. And this research is expected to help KTM to implement the best management as the approach taken by LRT management. KTM can also take the example of other countries' approaches such as Japan where rail transportation is the main transportation for Japanese people.

Determine CTQ based on important elements that consumers want and these elements are made into CTQ and each CTQ has a different type of disability [3].

Qureshi et al., [4] conducted a study to determine the level of customer satisfaction in an effort to reduce process variation and waste in its business processes using the Six Sigma methodology.

McAdam et al., [5] conducted research at the strategic and operational levels using Six Sigma Level measures at the Call Center using the first 2 methods of measuring at the Customer sigma level and second at measuring performance of the strategy and operational implementations that have been carried out, this study conducted in an effort to make sustainable business improvement. 


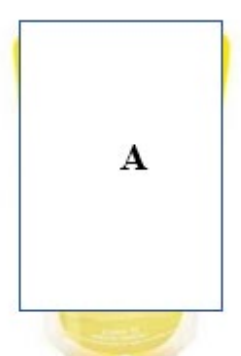

Figure 1. 1 Types of Cooking Oil Brand A, B and C.

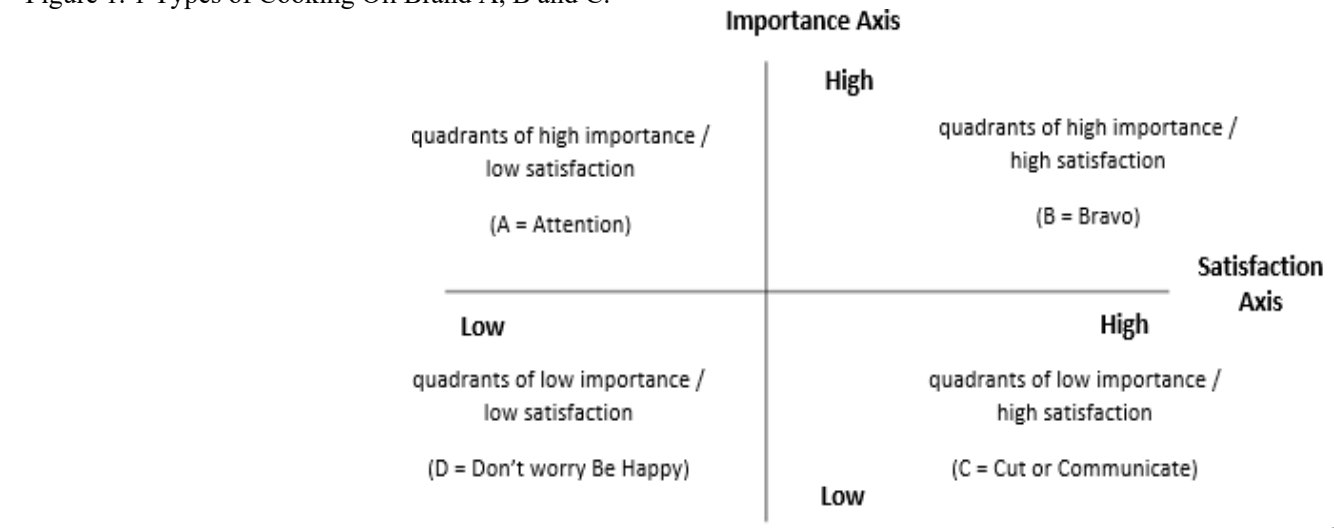

Figure 2. The satisfaction axis quadrant vs. the importance axis.

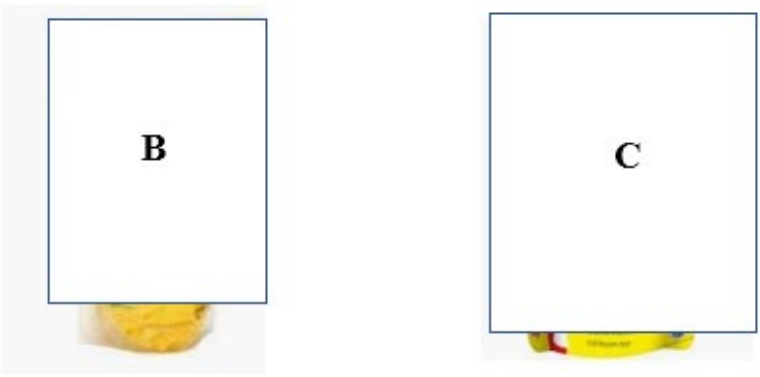

Table 1.

Data from the questionnaire

\begin{tabular}{lcccccc}
\hline \hline \multirow{2}{*}{ CTQ } & \multicolumn{2}{c}{ BRAND A } & \multicolumn{2}{c}{ BRAND B } & \multicolumn{2}{c}{ BRAND C } \\
\cline { 2 - 7 } & $\begin{array}{c}\text { RATING OF } \\
\text { INTEREST }\end{array}$ & $\begin{array}{c}\text { RATING OF } \\
\text { SATISFAC TION }\end{array}$ & $\begin{array}{c}\text { RATING OF } \\
\text { INTEREST }\end{array}$ & $\begin{array}{c}\text { RATING OF } \\
\text { SATISFACTION }\end{array}$ & $\begin{array}{c}\text { RATING OF } \\
\text { INTEREST }\end{array}$ & $\begin{array}{c}\text { RATING OF } \\
\text { SATISFACTION }\end{array}$ \\
\hline CLEAR & 5 & 4.2 & 4.6 & 4.6 & 4.8 & 4.06 \\
NOT SETTLING & 4 & 3.9 & 3.96 & 3.93 & 3.9 & 3.83 \\
NOT FAST TURBID & 5 & 3.2 & 4.8 & 3.3 & 4.7 & 3.4 \\
NOT PAIN IN & 4 & 4 & 3.96 & 3.96 & 4 & 4 \\
THE TROAT & 5 & 3.2 & 4.86 & 3.16 & 4.46 & 4.43 \\
LOW PRICE & 3 & 3 & 3 & 3 & 3 & 3 \\
VARIATION OF & 3 & & & & & \\
PACKING WEIGHT & & &
\end{tabular}

Table 2.

Rating Score

\begin{tabular}{lc}
\hline \multicolumn{1}{c}{ RATING } & SCORE \\
\hline Rating of Satisfaction - low & Satisfaction score smaller than 4 (1-5) \\
Rating of Satisfaction - high & Satisfaction score greater or equal to 4 \\
Rating of interest - low & Interest score smaller than 3 (1-5) \\
Rating of interest - high & Interest score greater or equal to 3 \\
\hline \hline
\end{tabular}

Table 3.

Bimoli Oil data sufficiency test

\begin{tabular}{llcrrc}
\hline \hline No & & Bimoli Oil data sufficiency test & \\
\hline 1 & CLEAR & CTQ & 30 & $\mathrm{~N}^{\prime}$ & Note \\
2 & NOT SETTLING & 30 & 6.4 & Sufficient \\
3 & NOT FAST TURBID & 30 & 10.5 & Sufficient \\
4 & NOT PAIN IN THE TROAT & 30 & 10.05 & Sufficient \\
5 & LOW PRICE & 30 & 14.9 & Sufficient \\
6 & VARIATION OF PACKING WEIGHT & 30 & 0 & Sufficient \\
\hline \hline
\end{tabular}

\section{II.RESEARCH METHOD}

This study uses primary data types conducted by distributing questionnaires, where the primary data itself is data obtained or collected by researchers directly from the data source. To get primary data, researchers must collect it directly.

Techniques that researchers can use to collect primary data include observation, interviews, focus groups (FGD) and questionnaires.

In addition also using secondary data, where secondary data is obtained from the literature relating to the method 


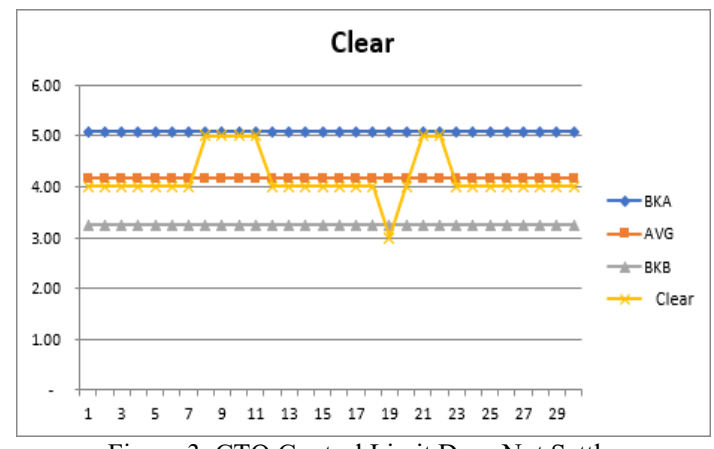

Figure 3. CTQ Control Limit Does Not Settle.

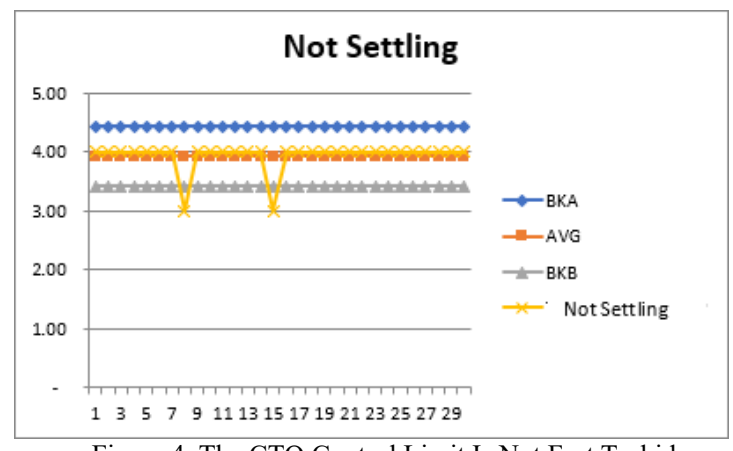

Figure 4. The CTQ Control Limit Is Not Fast Turbid.

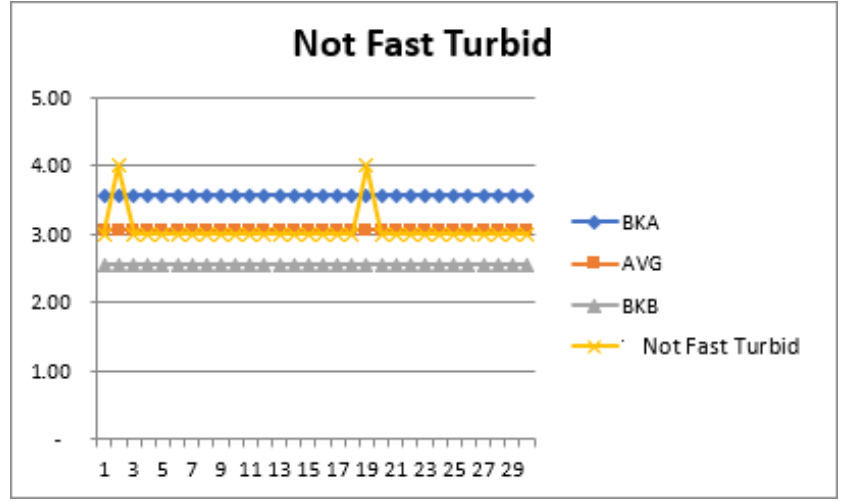

Figure 5. CTQ Control Limit No Pain.

Table 4.

The Homogeneity Data Test of Oil Brand A

\begin{tabular}{lccccccc}
\hline \multicolumn{1}{c}{ CTQ } & BKA & BKB & X & SD & Min Data & Max Data & Note \\
\hline CLEAR & 5.08 & 3.24 & 4.17 & 0.46 & 3 & Homogeneous \\
NOT SETTLING & 4.44 & 3.42 & 3.93 & 0.25 & 3 & 4 \\
NOT FAST TURBID & 3.57 & 2.55 & 3.07 & 0.25 & 3 & 4 \\
NOT PAIN IN THE TROAT & 4.6 & 3.32 & 3.97 & 0.31 & 3 & 5 \\
LOW PRICE & 3.7 & 2.48 & 3.1 & 0.3 & 3 & 4 \\
VARIATION OF PACKING & 3 & 3 & 3 & 0 & 3 & Homogeneous \\
WEIGHT & & & & & Homogeneous \\
\hline \hline
\end{tabular}

Table 5 .

Baseline Performance Measurement at the outcome level of Oil Barnd A

\begin{tabular}{|c|c|c|c|c|c|c|c|c|}
\hline CTQ & $\begin{array}{c}\text { Rating of } \\
\text { Interest }\end{array}$ & $\begin{array}{l}\text { Rating of } \\
\text { Satisfaction }\end{array}$ & $\begin{array}{l}\text { Gap Against } \\
\text { Customer's } \\
\text { interests }\end{array}$ & Satisfaction Targets & $\begin{array}{l}\text { Satisfaction Level } \\
\text { at this time }\end{array}$ & DPMO & Sigma & $\begin{array}{l}\text { Quadrant } \\
\text { Position }\end{array}$ \\
\hline$\overline{\text { CLEAR }}$ & 5 & 4.2 & 0.8 & 5 & $84 \%$ & 160000 & 2.49 & B \\
\hline NOT SETTLING & 4 & 3.9 & 0.1 & 5 & $78 \%$ & 220000 & 2.27 & B \\
\hline $\begin{array}{l}\text { NOT FAST } \\
\text { TURBID }\end{array}$ & 5 & 3.2 & 1.8 & 5 & $64 \%$ & 360000 & 1.86 & A \\
\hline $\begin{array}{l}\text { NOT PAIN } \\
\text { IN THE TROAT }\end{array}$ & 4 & 4 & 0 & 5 & $80 \%$ & 200000 & 2.34 & B \\
\hline $\begin{array}{l}\text { LOW PRICE } \\
\text { VARIATION }\end{array}$ & 5 & 3.2 & 1.8 & 5 & $64 \%$ & 360000 & 1.86 & A \\
\hline $\begin{array}{l}\text { OF PACKING } \\
\text { WEIGHT }\end{array}$ & 3 & 3 & 0 & 5 & $60 \%$ & 400000 & 1.75 & D \\
\hline
\end{tabular}

used. This research was conducted on 3 cooking oil products to determine CTQ from the outcome or customer side.

The data obtained is then processed using the sigma level method and also the determination of the quadrant position based on the level of importance compared to the level of satisfaction.

\section{III.RESULT AND DISCUSSION}

Based on the results of the questionnaire that was distributed to 30 housewives of Griya Asri housing complex, Purwosari - Pasuruan, who on average were more than 40 years old. 6 CTQs were obtained for the three types of cooking oil, namely: Clear, Not cloudy, No throat, No Sediment, Low price, and varied packaging weight. A summary of the data regarding the results of the questionnaire is shown in Table 1.

The level of satisfaction and importance of using the rating is used to measure the extent to which the product can meet customer desires, the rating score as in table 2, and to find out the results of the rating are in the quadrant position which can be seen in graph 1 .

The level of satisfaction and importance of using the rating is used to measure the extent to which the product can meet 
Table 6 .

Baseline Performance Measurement at the outcome level of Oil BarndB

\begin{tabular}{|c|c|c|c|c|c|c|c|c|}
\hline CTQ & $\begin{array}{l}\text { Rating of } \\
\text { Interest }\end{array}$ & $\begin{array}{c}\text { Rating of } \\
\text { Satisfaction }\end{array}$ & $\begin{array}{c}\text { Gap Against } \\
\text { Customer's interests }\end{array}$ & $\begin{array}{l}\text { Satisfaction } \\
\text { Targets }\end{array}$ & $\begin{array}{l}\text { Satisfaction Level at } \\
\text { this time }\end{array}$ & DPMO & Sigma & Quadrant Position \\
\hline CLEAR & 4.6 & 4.6 & 0 & 5 & $92 \%$ & 80000 & 2.9 & B \\
\hline NOT SETTLING & 3.96 & 3.93 & 0.03 & 5 & $79 \%$ & 210000 & 2.3 & A \\
\hline NOT FAST TURBID & 4.8 & 3.3 & 1.5 & 5 & $66 \%$ & 340000 & 1.91 & A \\
\hline $\begin{array}{l}\text { NOT PAIN } \\
\text { IN THE TROAT }\end{array}$ & 3.96 & 3.96 & 0 & 5 & $79 \%$ & 210000 & 2.3 & B \\
\hline LOW PRICE & 4.86 & 3.16 & 1.7 & 5 & $63 \%$ & 370000 & 1.83 & A \\
\hline $\begin{array}{l}\text { VARIATION OF } \\
\text { PACKING WEIGHT } \\
\end{array}$ & 3 & 3 & 0 & 5 & $60 \%$ & 400000 & 1.75 & $\mathrm{D}$ \\
\hline
\end{tabular}

Table 7.

Baseline Performance Measurement at the outcome level of Oil BarndC

\begin{tabular}{|c|c|c|c|c|c|c|c|c|}
\hline CTQ & $\begin{array}{l}\text { Rating of } \\
\text { Interest }\end{array}$ & $\begin{array}{c}\text { Rating of } \\
\text { Satisfaction }\end{array}$ & $\begin{array}{c}\text { Gap Against } \\
\text { Customer's } \\
\text { interests }\end{array}$ & $\begin{array}{c}\text { Satisfaction } \\
\text { Targets }\end{array}$ & $\begin{array}{l}\text { Satisfaction Level } \\
\text { at this time }\end{array}$ & DPMO & Sigma & Quadrant Position \\
\hline$\overline{\text { CLEAR }}$ & 4.8 & 4.06 & 0.74 & 5 & $81 \%$ & 190000 & 2.38 & $\mathrm{~A}$ \\
\hline NOT SETTLING & 3.9 & 3.83 & 0.07 & 5 & $77 \%$ & 230000 & 2.24 & A \\
\hline $\begin{array}{l}\text { NOT FAST } \\
\text { TURBID }\end{array}$ & 4.7 & 3.4 & 1.3 & 5 & $68 \%$ & 320000 & 1.97 & A \\
\hline NOT PAIN IN & & & & & & & & \\
\hline $\begin{array}{l}\text { THE } \\
\text { TROAT }\end{array}$ & 4 & 4 & 0 & 5 & $80 \%$ & 200000 & 2.34 & $\mathrm{D}$ \\
\hline $\begin{array}{l}\text { LOW PRICE } \\
\text { VARIATION OF }\end{array}$ & 4.46 & 4.43 & 0.03 & 5 & $89 \%$ & 110000 & 2.72 & B \\
\hline $\begin{array}{l}\text { PACKING } \\
\text { WEIGHT }\end{array}$ & 3 & 3 & 0 & 5 & $60 \%$ & 400000 & 1.75 & $\mathrm{D}$ \\
\hline
\end{tabular}

Table 8 .

Analysis of Results 3 types of cooking oil

\begin{tabular}{|c|c|c|c|c|}
\hline \multirow[b]{2}{*}{$\mathrm{NO}$} & \multirow[b]{2}{*}{ CTQ } & \multicolumn{3}{|c|}{ QUADRANT POSITION } \\
\hline & & BRAND AO & BRAND & BRAND C O \\
\hline 1 & CLEAR & $\mathrm{B}$ & $\mathrm{B}$ & A \\
\hline 2 & NOT SETTLING & $\mathrm{B}$ & A & A \\
\hline 3 & NOT FAST TURBID & A & A & A \\
\hline 4 & NOT PAIN IN THE TROAT & $\mathrm{B}$ & $\mathrm{B}$ & $\mathrm{D}$ \\
\hline 5 & LOW PRICE & A & A & $\mathrm{B}$ \\
\hline 6 & VARIATION OF PACKING WEIGHT & $\mathrm{D}$ & $\mathrm{D}$ & $\mathrm{D}$ \\
\hline
\end{tabular}

customer desires, the rating score as in table 2, and to find out the results of the rating are in the quadrant position which can be seen in graph 1 .

\section{DATA SUFFICIENCY TEST}

From the questionnaire data distributed, a data sufficiency test was conducted to ensure that the data collected was sufficiently objective by using the formula:

$$
N^{\prime}=\left(\frac{\frac{k}{s} \sqrt{\left(N_{\sum} x^{2}\right)-\left(\sum x\right)^{2}}}{\sum x}\right)^{2}
$$

Calculation of data sufficiency test can be seen in table 3 . In the data sufficiency test, if $\mathrm{N}^{\prime}$ has a value smaller than $\mathrm{N}$ $\left(\mathrm{N}>\mathrm{N}^{\prime}\right)$, it means that the data is declared sufficient.

\section{DATA HOMOGENEITY TEST}

Used to ensure that the data collected is from the same system and to separate data that has different characteristics. Calculation of uniformity test used formula:

$$
S D=\sqrt{\frac{\sum(X i-X)^{2}}{n}}
$$

The values of all dimensions do not exceed the control value so it can be said that the data meet the data uniformity test, for the graph of the upper and lower control limits for each CTQ can be seen in the figure 3-7.

\section{MEASUREMENT OF PERFORMANCE BASELINE AT THE OUTCOME LEVEL}

Performance Baseline measurements were carried out on 3 cooking oil products to determine the quadrant position of each CTQ and also can be known sigma level and DPMO calculations whose values are obtained from the sigma and DPMO values tables. The results can be seen in the table 5-7.

\section{ANALYSIS OF RESULT}

Based on the baseline measurement of performance at the outcome level for each cooking oil, it is summarized as shown in table 8 .

The result are: (1)CTQ is clear for brand A and B oils from the results of the questionnaire are in quadrant B (Bravo) which means a high level of importance is high satisfaction, which needs attention is brand $\mathrm{C}$ because it is in quadrant $\mathrm{A}$ (Attention) means that the level of importance is high but satisfaction low; (2)CTQ is Not Settling for Brand A Oil from the results of the questionnaire is in quadrant $\mathrm{B}$ (Bravo) which 


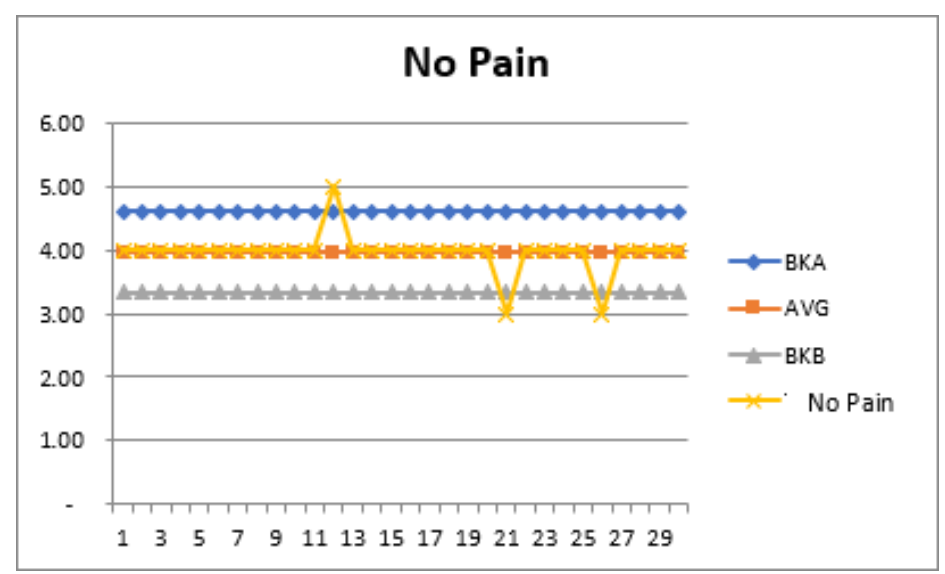

Figure 6. CTQ Control Limit Low Price.

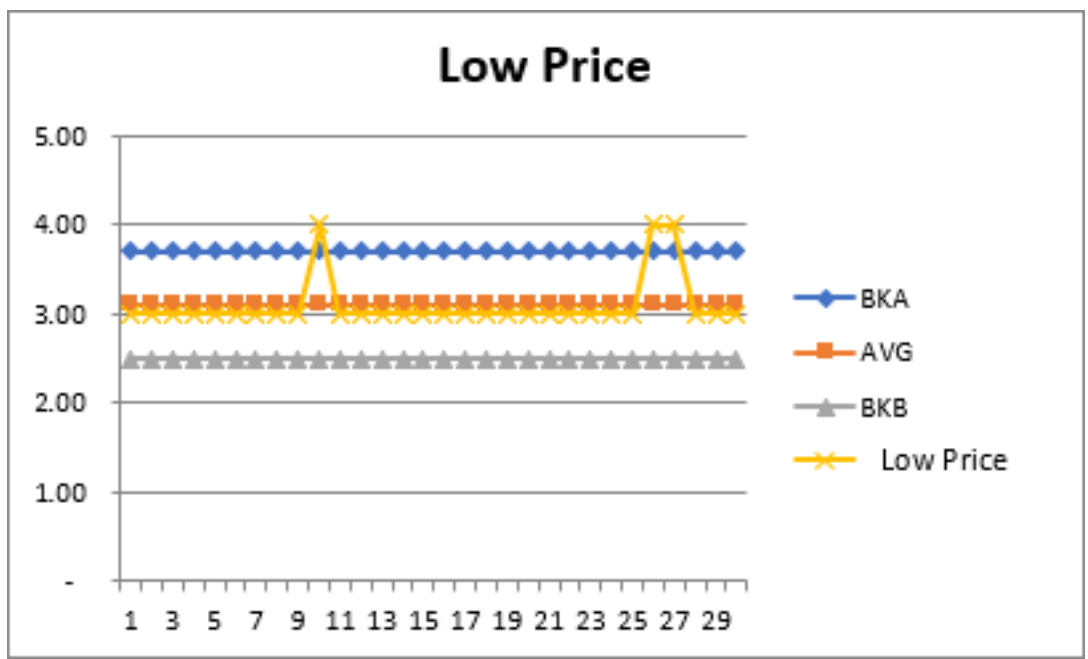

Figure 7. CTQ Control Limit Variation Of Packing Weight.

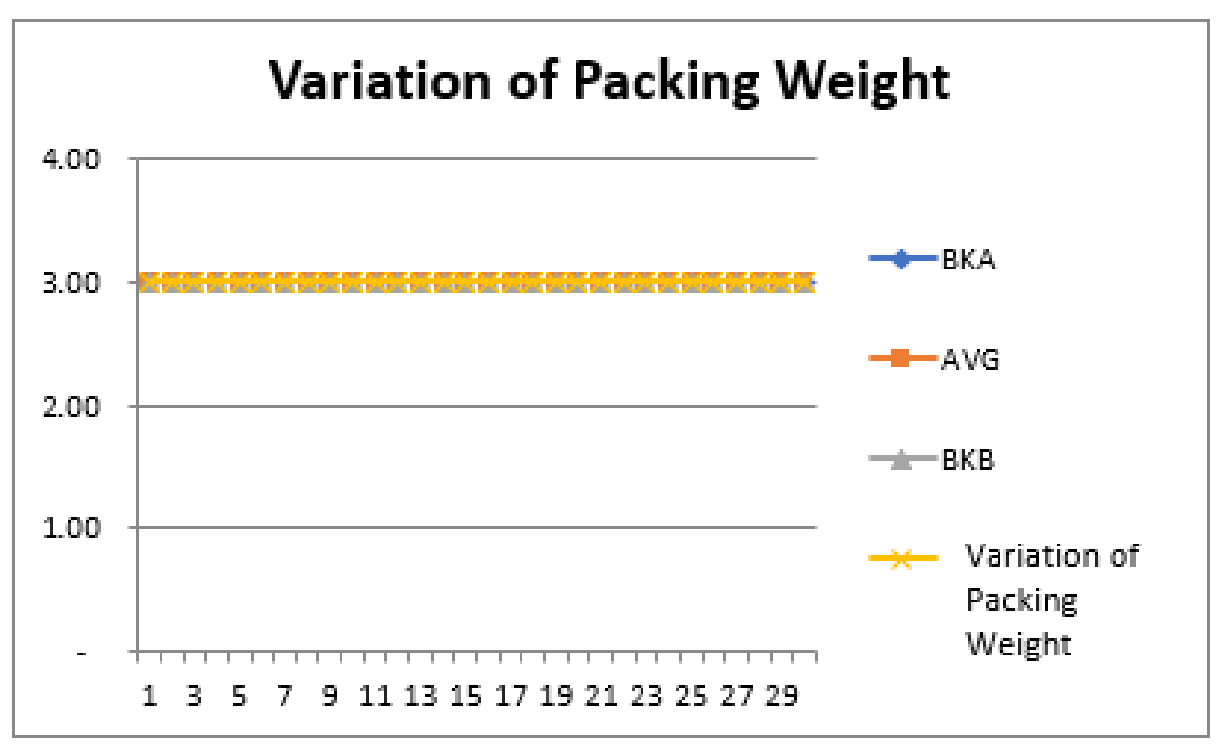

means high levels of high satisfaction, while brand B Oil and brand C Oil are in quadrant A (Attention) which means that the level of importance is high but satisfaction is low; (3)CTQ is Not Fast Turbid for all types of oil from the results of the questionnaire is in the A quadrant (Attention) which means that the level of importance is high but satisfaction is low; (4)CTQ is No pain in the throat for Brand Oil A and Brand Oil B from the results of the questionnaire is in quadrant B (Bravo) which means a high level of importance of high satisfaction, while Brand C Oil is in quadrant D (Don't Worry Be Happy) which means that the level low interest and low satisfaction; (5)CTQ is Low prices for brand A oil and brand $\mathrm{B}$ oil from the results of the questionnaire are in quadrant $\mathrm{A}$ (Attention) which means high importance but low satisfaction, while brand C Oil is in quadrant B (Bravo) which means that the level of importance is high and the level of satisfaction is also high; (6)CTQ Is Packaging Weight varies for the three types of oil from the questionnaire results are in 


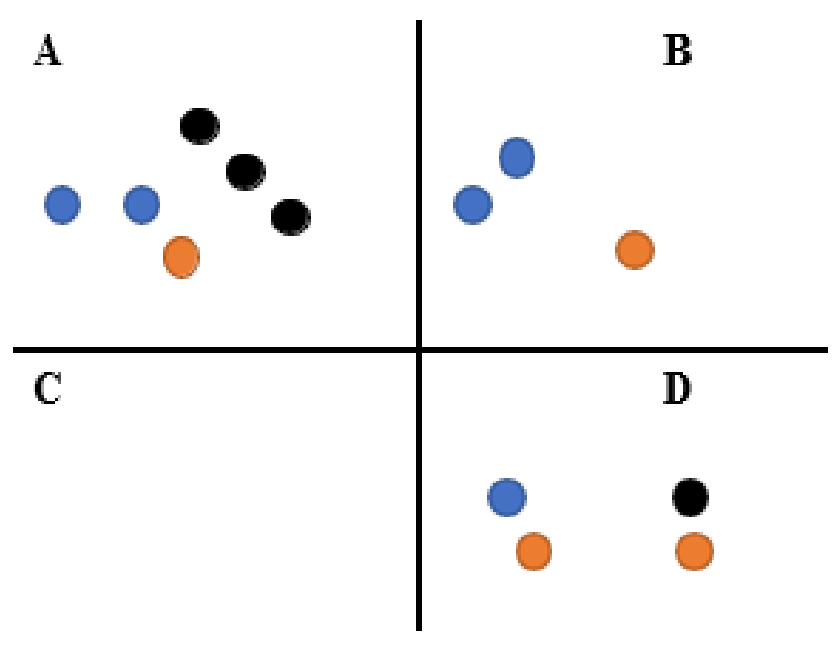

Note:

\section{Oil Brand $\mathrm{A}=$}

Figure 8. Quadrant Overview.

quadrant D (Don't Worry Be Happy) which means that the level of importance is low the level of satisfaction is also low. In the picture in the quadrant as in the figure 8.

\section{CONCLUSION}

Based on the research that has been done, the following conclusions are obtained: (1)CTQ is the most for quadrant A position so it needs special attention for oil producers is Sovia oil with clear criteria, does not precipitate and does not quickly cloudy, next is Sunco Oil for the criteria of not settling, not turbid fast and cheap prices; (2)CTQ with a high level of satisfaction that requires quality to be maintained by producers in order to be able to meet customer desires and be in quadrant B is Bimoli Oil for clear criteria, does not settle and is not scaly in the throat; (3)In terms of sigma level, CTQ with the lowest sigma value for Brand A Oil is the criteria not quickly cloudy with the number 1.86 , Brand Oil B is the cheap price criteria with the number 1.83 and for the brand $\mathrm{C}$ oil that is not quickly cloudy with the number 1.97 . The conclusion from the sigma level can also be taken into consideration for producers to make improvements and improvements.

\section{REFERENCES}

[1] D. Kim, "CTQ for service quality management using web-based VOC: With focus on hotel business," J. Theor. Appl. Inf. Technol., vol. 96, no. 22, pp. 7464-7472, 2018.

[2] R. Mustapha and N. F. Habidin, "Using DMAIC in Improvement of Customer Satisfaction and Facilities provided at Commuter Stations," Int. J. Acad. Res. Bus. Soc. Sci., vol. 6, no. 12, pp. 821-836, 2017, doi: 10.6007/ijarbss/v6-i12/2564.

[3] H. Fransiscus, C. P. Juwono, and I. S. Astari, "Implementasi Metode Six Sigma DMAIC untuk Mengurangi Paint Bucket Cacat di PT X," J. Rekayasa Sist. Ind., vol. 3, no. 2, pp. 53-64, 2014, doi: 10.26593/jrsi.v3i2.1297.53-64.

[4] M. I. Qureshi, N. Bashir, K. Zaman, N. Sajjad, and S. Fakhr, "Customer Satisfaction Measurement and Analysis Using Six Sigma in Telecom Sector of Pakistan," Eur. J. Sustain. Dev., vol. 1, no. 1, pp. 53-68, 2012, [Online]. Available: https://www.ecsdev.org/images/V1I1/volume 1 issue 1 4.pdf.

[5] R. McAdam, J. Davies, B. Keogh, and A. Finnegan, "Customer- orientated Six Sigma in call centre performance measurement," in International Journal of Quality \& Reliability Management, 2009, vol. 26, no. 6, pp. 516-545, doi: 10.1108/02656710910966110. 